\title{
Determinants of economic achievement for women entrepreneurs in Ethiopia
}

\author{
Beshir Shaku Beriso(D)
}

\author{
Correspondence: beshirshk2@gmail. \\ com \\ Department of Statistics, Haramaya \\ University, P. O. Box 138, Dire Dawa, \\ Ethiopia
}

\begin{abstract}
The main objective of this paper is to assess the determinants and challenges of economic achievement for women entrepreneurs in Ethiopia. The study used 698 sample women entrepreneurs selected randomly from a total of 2450 respondents. The data were analyzed using descriptive statistics and multiple linear regression models. The results revealed that there is a high rate of challenges for divorced (30\%) and widowed (41\%) women entrepreneurs in the selected area. The results of multiple linear regression show that the educational level, family size, region (SNNP, Gambella, Harari, Dire Dawa, and Addis Ababa), parents' educational level, number of financially dependent people, business experiences, and access to raw materials were positive predictors of the income of women entrepreneurs. It is also found that entrepreneurial area (Afar, Amhara, and Oromiya), marital status (divorced and widowed), entrepreneurship training, enterprise's license, and lack of supporting institutions were negatively related with the income of women entrepreneurs. Therefore, improving entrepreneurs' and parents' education, providing entrepreneurship training, sharing business experiences, supporting entrepreneurs is the main instrumental in minimizing the factors affecting the income of women entrepreneurs. Moreover, it is advisable if the business participation status of women be assessed periodically to monitor the situation and to take appropriate measures for combating and preventing the challenges facing women entrepreneurs in economic growth.
\end{abstract}

Keywords: Multiple linear regression, Economic growth, Entrepreneurship, Ethiopia

\section{Background}

Entrepreneurship is the engine of economic growth and wheel that pedal the vehicle of economic development through the process of creating jobs, revenue generation, poverty alleviation, and wealth by devoting the necessary skills, time, and effort, assuming the accompanying financial, sometimes physical, and social risks to reap the resulting monetary rewards and personal happiness (Hisrich, Peteris, \& Shepherd, 2008; Shane \& Venkatarman, 2000; Wang, Walker, \& Redmond, 2006). Enterprises are playing a crucial role in contributing to economic growth and development of the countries through creating new jobs, reducing unemployment, increasing productivity by bringing innovation, and speeding up structural changes by forcing existing businesses to reform and increasing competition (Baron, 2007).

(c) The Author(s). 2021 Open Access This article is licensed under a Creative Commons Attribution 4.0 International License, which permits use, sharing, adaptation, distribution and reproduction in any medium or format, as long as you give appropriate credit to the original author(s) and the source, provide a link to the Creative Commons licence, and indicate if changes were made. The images or other third party material in this article are included in the article's Creative Commons licence, unless indicated otherwise in a credit line to the material. If material is not included in the article's Creative Commons licence and your intended use is not permitted by statutory regulation or exceeds the permitted use, you will need to obtain permission directly from the copyright holder. To view a copy of this licence, visit http://creativecommons.org/licenses/by/4.0/. 
Women entrepreneurs are the women or group of women, who initiate, organize, and operate a business enterprise and who have recognized an opportunity and started, developed, and grown a business venture successfully. Women entrepreneurs have used creative, practical, and innovative approaches to convert an opportunity into commercial reality. They are also actively involved in the operation of the enterprise as a manager or administrator and generate employment for themselves and others (Pandian \& Jesurajan, 2011; Smile, 2008).

Women entrepreneurs are simply women that participate in entrepreneurial activities, who take the risks involved in uniquely combining resources to take advantage of the opportunity identified in their immediate environment through the production of goods and services (Okafor \& Mordi, 2010). The involvement of women entrepreneurs in entrepreneurship is believed to be one of the efforts to alleviate poverty and unemployment problems in most of the developing or emerging countries. Not only reducing poverty and unemployment but also increasing success stories of women entrepreneurs has encouraged other women (housewives or employed) to run their businesses (Bhardwaj, 2014). The success of women entrepreneurs is emerging nationally and globally (Agarwal \& Lenka, 2016).

Nowadays, women empowerment has been increasing so rapidly all over the world and women are starting their businesses to seek greater control over their personal and professional lives. It can be seen that women entrepreneurship is a growing phenomenon and has had a significant economic impact on all economies. Women entrepreneurship has been recognized as providers of social upgrading, promoting economic regeneration and growth, and job creation. Women's participation in economic expansion has been also documented as very important for a country, particularly their participation in the area of entrepreneurship. It is also considered as the central force for economic change that requires more women to be involved in its operations (Nieman \& Nieuwenhuizen, 2003). However, promoting women entrepreneurship requires more concentration to be focused upon problems that hamper women entrepreneurs. This is because women entrepreneurs are crucial in the economic growth of most countries around the world (Normaizatul, Norhanizah, \& Hamidah, 2017; Okafor \& Mordi, 2010).

Most micro and small enterprises in Ethiopia are operated by women entrepreneurs contribute significantly to the national economy in terms of job creation and alleviation of poverty among impoverished women. But, the degree of recognition and strategic support provided to the sector is grossly insufficient (Eshetu \& Zeleke, 2008; Ethiopian Economic Association, 2004). Ensuring women's active participation in the country's economic development and equal benefit from economic growth, increasing participation in the social sector and empowerment of women by abolishing harmful traditional practices is important to generate more income (Melat, 2015).

Women entrepreneurs in Ethiopia can play an important role in the micro and small enterprise development provided the government takes the necessary steps to mitigate the problems and hardships faced by them. The purpose of microenterprise development in such contexts is not only to increase women's access to income but also to motivate a process of empowerment for women through which they can gain power and status in the household, market, and community (Jemal, 2013). Most business enterprises in developing countries like Ethiopia are micro and small enterprises face 
various challenges including lack of processed technological information, inadequate training capabilities, lack of access to financial, availability of raw material, poor infrastructure base, government mobility, and others (Roomi \& Parrott, 2008; Singh \& Belwal, 2008; Tambunan, 2009; United Nations, 2006).

The extreme challenge to understanding the role of entrepreneurship in economic growth and development has been lacking meaningful data to assess the determinants of economic achievement for women entrepreneurs. Moreover, there has been a development of new data sources like the Enterprises Data Survey collected by the World Bank which has encouraged many empirical studies, in the developed countries, on the factors of entrepreneurship. Roomi and Parrott (2008) pointed out that access to market, finance, government mobility, availability of raw material, lack of knowledge, experience to run a business, high costs of machinery or equipment, and difficulty in availability of labor are the problems face women entrepreneurs. Tambunan (2009) noted that education and training are vital components for business success which implies that the educated women entrepreneurs will have a better employment opportunity in their lives such as highly paid and thus will reduce their involvement in entrepreneurship.

According to the findings of Beshir, Adem, and Belaineh (2016), the educational level of household heads is an important component for participation in entrepreneurial activities which implies that higher education may facilitate entry in the business activities, can enhance the managerial ability of the individual, and hence increase the propensity to undertake to participate in entrepreneurial activity. In line with this, the economic background of parents is also an essential component to participate in different entrepreneurial activities which imply that the economy of parents influences household heads directly or indirectly to generate their income.

According to Aregash (2005), 98\% of business firms in Ethiopia are micro and small enterprises (MSEs), out of which small enterprises represent $65 \%$ of all businesses. On the other hand, more than half of all women entrepreneurs in Ethiopia often face gender-related challenges related to establishing new businesses as well as operating or expanding existing businesses (Amha \& Admassie, 2004). Zewde and Associates (2002) estimated that the low representation of women entrepreneurs in the small-scale manufacturing sector could be attributed to a number of factors such as low levels of education, lack of opportunities for training for women, heavy household chores that leave women less time to devote to their businesses, lack of contact with and exposure to the business world, and meager financial and human capital at the disposal of the women concerned. Besides, socio-cultural problems play their part in the shaping of female businesses. Furthermore, major constraints on women's participation in developmental activity lie on the socio-cultural belief of the society, particularly as it governs marriage and property ownership by women in particular, and also in the patriarchal social system of the society in general.

Women entrepreneurs in Ethiopia suffer from gender discrimination in society due to socio-cultural barriers, multiple responsibilities, underdeveloped enterprise culture, an inadequate support system for businesses, and underdeveloped markets and infrastructure (Desta, 2010). In line with this, women entrepreneurs in Ethiopia are often discriminated against in terms of approval of applications for business licenses and loans from money lending institutions such as commercial banks (Wole, 2004). 
Studies conducted by Geda, Shimeles, and Weeks (2009) and Rahmato (2004) have shown that women entrepreneurs in Ethiopia often fail due to gender-based discrimination in terms of access to finance, tax assessment, approval of new business ventures, and skills development. Additionally, Amha and Narayana's (2004) findings have been shown that women are disadvantaged due to culture, religion, and tradition. For instance, many women face difficulty in raising credit finance from banks as well as borrowing via informal networking. The survey shows that women-headed firms started their businesses with an average capital of $\$ 2115$ while male-headed businesses started their businesses with an average capital of $\$ 3161$. On average 5.5\%, 10.5\%, 10.5\%, and $7 \%$ of female-headed enterprises managed to get credit from banks, microfinance, Iqqub schemes, and personal donations, respectively. The corresponding figure for male-headed firms was $12.7 \%, 8.4 \%, 13.7 \%$, and $4.6 \%$, respectively.

While the problem of women entrepreneurs' economic growth in Ethiopia is relatively studied or documented, its specific determinants are not well understood. To increase the participation of entrepreneurs, one must understand the challenges and factors affecting them significantly impair economic development and reduce involvement in business in particular and economic growths of countries like Ethiopia in general. Most previous studies conducted on determinants and challenges of women entrepreneurs in different countries employed descriptive statistics. The current study used descriptive statistics to identify demographic characteristics, socioeconomic characteristics, and challenges of women entrepreneurs. Besides, the current study applied multiple linear regression models to determine the factors that affect the economic achievement of women entrepreneurs in Ethiopia; however, most of the previous studies did not employ this model. The main objective of this study is to assess the determinants and challenges of women entrepreneurs' economic achievement in Ethiopia.

\section{Literature review}

Entrepreneurship for women is frequently seen as a drive out of poverty and a stride towards parity (Bushell, 2008). Women entrepreneurs make a substantial contribution to national economies through their participation in start-ups and their growth in small and medium businesses. It is also found that investment in women is now documented as vital to achieving sustainable development. However, there were many challenges or determinants of enterprises such as government rules and regulations, low levels of education and training, limited access to resources limit productivity, lack of access to finance, assets, information technology, infrastructure, and other facilities that enable their efficiency and business growth, hinder the competence and growth of the economy as a whole (United Nations, 2006).

According to statements of Olomi and Sinyamule (2007), women became the main breadwinners. The other explanation for the increased prominence of this motive is that the number of single mothers has been increasing, and many do not have any means of earning their livelihood other than self-employment. The empirical studies conducted by Nelso and Ikandilo (2011) pointed out that poor infrastructure, lack of business premises, the decline in business, and lack of premise space were the major challenges of micro-entrepreneurs. Other previous studies also noted that the main constrains on the performance of female-owned enterprises were education, training, business experience, discriminations, networking or socialization, and unwillingness to 
take the risk, negative attitude towards the business owned by women-particularly by men, and inadequate and affordable business premises (Nchimbi, 2002).

Coleman (2002) reveals that small size, limited prospects for profitability and failure to provide collateral for obtaining loans, and the nature of women's involvement in business were the major challenges of women participated in entrepreneurial activities. The findings of Teresia (2014) revealed that women empowerment, training, and sharing of information; provision of networks to enable marketing; provision of working areas near home location because of family reasons; the building of self-confidence and esteem; and risk-taking training to improve formal market credits, thus growing their enterprises were found to be major challenges facing women entrepreneurs in Africa.

Empirical evidence shows that women entrepreneurs generally face three types of problems like business problems (securing finance, marketing, and personnel), personnel problems (lack of family support or family conflict, lack of formal education and time), technical problems (non-availability of raw material, shortage of electricity, and lack of skills). Also, the non-availability of raw material, lack of related skills, unskilled group members, and shortage of working capital are the major technical problems faced by women entrepreneurs (Sumaira, Madiha, \& Muhammad, 2013). Also, according to Ray and Ray (2011), the biggest obstacles and difficulties for the development of enterprises are located within the availability of financial resources, information, education, and markets. Singh and Belwal (2008) also identified different factors that were also considered as a hindrance for women entrepreneurs. These factors include securing finance for business; lack of entrepreneurial and management competence and exposure; problems in finding markets and distribution networks; absence of technological know-how; lack of family support, society, and government is a problem and poor education and training.

Wolday, Tassew, Eyoual, and Aregawi (2015) argue that the age of household head, level of education, societal attitude towards entrepreneurship, and social networks (knowing someone in business) are significant in influencing potential entrepreneurship and entrepreneurial intentions in Ethiopia. Another study has emphasized that gender, education status, age of the owner, work experience of the owner, family background, and business characteristics like the industrial sector, age of business, legal status and formality, and other characteristics influence the business success. However, contrary to the expectation, only age of business, having a recording system, and borrowing from the external source were seen as significant in predicting business success (Wasihun, 2010).

\section{Methods}

\section{Data source and analytical methods}

This study used the 2014 Ethiopian Enterprise Survey data (ESD) collected by the World Bank (World Bank, 2014) from February 2014 to April 2014. It is the second survey conducted in Ethiopia as a part of the worldwide. The 2014 Ethiopian socioeconomic survey was designed to provide estimates for the socio-economic and demographic variables of interest for Ethiopia as a whole; urban and rural areas and 11 geographic administrative regions ( 9 regions and 2 city administrations), namely, Tigray, Afar, Amhara, Oromiya, Somali, Benishangul-Gumuz, Southern Nations Nationalities 
and Peoples, Gambella and Harari regional states and two city administrations, Addis Ababa and Dire Dawa. The data were collected to provide basic information on the enterprises in Ethiopia. For sample selection, a simple random sampling technique was adopted to select a representative sample. Finally, after cleaning the data based on relevant variables, this study selected a total of 698 women entrepreneurs out of $2450 \mathrm{fe}-$ male respondents.

\section{Multiple linear regression model}

Multiple regressions are a type of regression in which we have a dependent and two or more independent variables. If $Y$ is a continuous dependent variable and $X_{1}, X_{2}, \ldots, X_{k}$ is any $k$ independent variables, then the linear regression equation of $Y$ on these variables is given by

$$
Y=\beta_{0}+\beta_{1} X_{1}+\beta_{2} X_{2}+\ldots+\beta_{k} X_{k}+\varepsilon_{i}
$$

Where $\varepsilon_{i}$ is the random term that is included to take care of the contribution of the variables not known to the researcher and thus not included in the model. The estimates of coefficients of the regression equation are obtained using the method ordinary least squares (OLS). Ordinary least squares assumes that the random term follows a normal distribution with zero mean and constant variance. The successive values of the random term are also assumed to be independent. The ordinary least squares assumes also that the explanatory variables are non-stochastic and they are not perfectly linearly related to one another (Gujarati \& Sangeetha, 2007; Koutsoyiannis, 2001). A coefficient of an independent variable in regression equation refers to the amount by which $y$ changes when the independent changes by one (for quantitative independent variable) and the amount of change in $y$ as one shift from the base category to the category of interest (for qualitative/categorical independent variable).

The least-squares estimate is also the maximum likelihood estimate if the errors $\varepsilon_{i}$ are independent with equal variance and normally distributed. In any case, the leastsquares estimator of a vector of linear regression coefficients $\beta$ is given by

$$
\hat{\beta}=\left(X^{\prime} X\right)^{-1} X^{\prime} Y
$$

In practice, the computation is performed using various efficient matrix decompositions without ever fully computing $X^{\prime} X$ or inverting it. For this study, it is merely useful to realize that is $\beta^{\wedge}$ a linear function of the outcomes $y$ considering the predictors $X$ is a linear combination of the data. The variation in the dependent variable can be partitioned into a part due to regression on the independent variables and a residual term. The latter divided by its degrees of freedom (the residual mean square) gives an estimate of $\sigma^{2}$ and the ratio of the regression mean square to the residual mean square provides an $F$-test of the hypothesis that $\beta_{0}, \beta_{1}, \ldots, \beta_{q}$ takes the value 0. Individual regression coefficients can be assessed by using $t$-statistics, the ratio:

$$
t=\frac{\hat{\beta}_{i}}{\operatorname{Se}\left(\hat{\beta}_{i}\right)}
$$

The presence of multicollinearity among the variables seriously affects the parameter estimates of any regression model. The variance inflation factor (VIF) technique is 
employed to detect the problem of multicollinearity for the continuous variables (Gujarati, 2004).

Variance inflation factor (VIF) can be defined as

$$
V I F\left(X_{j}\right)=\frac{1}{1-R_{j}^{2}}
$$

$R_{j}^{2}$ is the squared multiple correlation coefficient between $X_{j}$ and other explanatory variables. A larger value of variance inflation factor indicates the presence of multicollinearity among variables. As a rule of thumb, if a variance inflation factor of a variable exceeds 10 , the variable is said to be highly collinear with explanatory variables.

Regression with the ordinary least square method of estimation was used to identify the determinants of women entrepreneurs' income in this study, as income is a continuous variable.

\section{Results and discussion \\ Descriptive statistics results}

Results of the study show that out of the 698 sampled households, $22 \%, 7 \%, 30 \%$, and $41 \%$ were married, single, divorced, and widowed, respectively. The distribution of religion sample households shows that $60 \%$ are Orthodox, $24 \%$ are Muslim, $14 \%$ are Christian Protestant, and $2 \%$ belong to other religious groups. The average family size in the study area is 4.72 with a standard deviation of 2.67. The mean age of the household head is 45.86 years with a standard deviation of 15.58 . The average number of financially dependent people on households is 1.60 with a standard deviation of 1.56 . Although, distribution of parents' educational level shows that $81 \%, 9 \%, 7 \%, 2.6 \%$ were illiterate, basic/adult education, elementary, and secondary and above, respectively (see Table 1).

Results in Table 2 reveal that among 698 sampled women entrepreneurs, 53\% of them were running their business in rural whereas $47 \%$ of them run in urban areas. The results also show that $46 \%$ of the women entrepreneurs were offered entrepreneurship training before starting a business while $54 \%$ of them were not received the training. The mean number of training received is 0.66 with a standard deviation of 0.754 . The distribution of the main source of capital to start-up enterprises was $38 \%$ were agriculture, $42 \%$ were non-farm self-employment income, $15 \%$ were family/friends in the community, and $5 \%$ belonged to others.

The Table 3 presents that raising initial finance (64\%), access to market (54\%), lack of business information (51\%), access raw materials (52\%), lack of supporting institutions (60\%), and livelihood condition of entrepreneurs' (73\%) are the major the challenges that faced women entrepreneurs in entrepreneurial activities.

\section{Econometric analysis}

Table 4 presents the estimated effects of the multiple linear regression model on factors affecting the economic achievement of women entrepreneurs. In what follows, the researcher presents and discusses the determinants of the economic achievement of women entrepreneurs. Then, the author concludes and recommends. 
Table 1 Summary of descriptive statistics results

\begin{tabular}{lll}
\hline Variable & Category/measure & Count/value (\%) \\
\hline Age of household in years & Mean & 45.86 \\
Family size & Standard deviation & 15.58 \\
No. of financially dependent people & Mean & 4.72 \\
& Standard deviation & 2.67 \\
Religion & Mean & 1.60 \\
& Standard deviation & 1.56 \\
& Muslim & $164(24)$ \\
Marital status & Orthodox & $418(60)$ \\
& Protestant & $100(14)$ \\
Parents' educational level & Others & $16(2)$ \\
& Married & $156(22)$ \\
& Single & $46(7)$ \\
& Divorced & $209(30)$ \\
& Widowed & $287(41)$ \\
& Illiterate & $565(81)$ \\
& Basic/adult education & $60(9)$ \\
& Elementary & $53(8)$ \\
& Secondary and above & $21(2.6)$ \\
& Agriculture & $465(67)$ \\
& Running own business & $36(5)$ \\
& Daily laborer & $190(27)$ \\
\hline
\end{tabular}

Source: World Bank Data, 2014

Table 2 Summary results in regard to enterprises

\begin{tabular}{lll}
\hline Indicators/variables & Category/measure & Count/value (\%) \\
\hline Entrepreneurial area/residence & Rural & $370(53)$ \\
Entrepreneurship training & Urban & $328(47)$ \\
& Received & $321(46)$ \\
Number of training received & Not received & $377(54)$ \\
& Mean & 0.660 \\
Previous business experience & Standard deviation & 0.754 \\
Main source of capital to start-up enterprise/business & Yes & $316(45)$ \\
& No & $382(55)$ \\
& Non-farm self-employment income & $291(42)$ \\
Enterprise's license & Bank/cooperative loan & $37(5)$ \\
& Family/friends in the community & $106(15)$ \\
& Yes & $389(44)$
\end{tabular}


Table 3 Summary results of the challenges face women entrepreneurs

\begin{tabular}{|c|c|c|}
\hline Indicators & Category/measure & Count/value (\%) \\
\hline \multirow[t]{2}{*}{ Legal and regulatory environment } & Yes & $369(53)$ \\
\hline & No & $329(47)$ \\
\hline \multirow[t]{2}{*}{ Raising initial finance } & Yes & $448(64)$ \\
\hline & No & $250(36)$ \\
\hline \multirow[t]{2}{*}{ Access to market } & Yes & $379(54)$ \\
\hline & No & $319(46)$ \\
\hline \multirow[t]{2}{*}{ Lack of business information } & Yes & $351(51)$ \\
\hline & No & $347(49)$ \\
\hline \multirow[t]{2}{*}{ Securing business premises } & Yes & $321(46)$ \\
\hline & No & $377(54)$ \\
\hline \multirow[t]{2}{*}{ Supply of raw material (Input) } & Yes & $361(52)$ \\
\hline & No & $337(48)$ \\
\hline \multirow[t]{2}{*}{ Lack of supporting institutions } & Yes & $419(60)$ \\
\hline & No & $279(40)$ \\
\hline \multirow[t]{2}{*}{ Enterprise registration and permit regulations } & Yes & $331(47)$ \\
\hline & No & $367(53)$ \\
\hline \multirow[t]{2}{*}{ Harmful traditional culture } & Yes & 274(39) \\
\hline & No & $424(61)$ \\
\hline \multirow[t]{2}{*}{ Economic policy (uncertainty) } & Yes & 289(41) \\
\hline & No & $409(59)$ \\
\hline \multirow[t]{2}{*}{ Un-enabling working environment } & Yes & $310(44)$ \\
\hline & No & $388(56)$ \\
\hline \multirow[t]{2}{*}{ Livelihood condition of entrepreneurs' } & Yes & $512(73)$ \\
\hline & No & $186(27)$ \\
\hline
\end{tabular}

Source: World Bank Data, 2014

The multiple linear regression model result shows that among the proposed explanatory variables for affecting yearly income (capital) of women entrepreneurs: educational level, family size, entrepreneurial area (rural), region (Afar, Amhara, Oromiya, Southern Nations Nationalities and Peoples, Gambella, Harari, Dire Dawa, and Addis Ababa), marital status (divorced and widowed), parents educational level (basic/adult education, secondary school and above), number of financially dependent people, entrepreneurship training (no), previous business experiences (no), enterprise's license (yes), the supply of raw material (no), and lack of supporting institutions (no) significantly affected the capital or income of women entrepreneurs (see Table 4 for a summary of the main results).

Entrepreneurship is a mechanism of economic growth and it is used to reduce unemployment and poverty through job creation. The involvement of women entrepreneurs in business activities is not only reducing poverty and unemployment but also increasing success stories of women entrepreneurs has encouraged other women to run their own businesses (Baron, 2007; Eshetu \& Zeleke, 2008; Nieman \& Nieuwenhuizen, 2003; Normaizatul et al., 2017; Wang et al., 2006). The current study is in agreement with the results of the above researchers which imply that the women entrepreneurs play an important role in the economic growth of countries. 
Table 4 Multiple linear regression results of parameter estimates

\begin{tabular}{|c|c|c|c|c|c|}
\hline Variables & Coef. & St. err & $t$ & $P / t /$ & Vif \\
\hline Age of household heads & 0.012 & 0.010 & 1.21 & 0.215 & 1.57 \\
\hline The educational level of the household head & 0.203 & 0.068 & 2.98 & 0.003 & 1.37 \\
\hline Family size & 0.020 & 0.006 & 3.33 & 0.002 & 1.39 \\
\hline Number of financially dependent peoples & -0.046 & 0.019 & -2.42 & 0.017 & 4.17 \\
\hline Entrepreneurial area of household head: $1=$ rural & -0.083 & 0.038 & -2.18 & 0.029 & 1.67 \\
\hline \multicolumn{6}{|l|}{ Region of household heads: } \\
\hline $2=$ Afar & -0.197 & 0.101 & -1.96 & 0.051 & 1.26 \\
\hline $3=$ Amhara & -0.458 & 0.071 & -6.45 & 0.000 & 3.91 \\
\hline 4 = Oromiya & -0.152 & 0.077 & -1.97 & 0.050 & 2.98 \\
\hline $5=$ Somalia & 0.158 & 0.101 & 1.56 & 0.121 & 3.22 \\
\hline $6=$ Benishangul Gomuz & -0.021 & 0.125 & -0.17 & 0.867 & 1.44 \\
\hline $7=S N N P$ & 0.266 & 0.092 & 2.89 & 0.004 & 5.96 \\
\hline $8=$ Gambella & 0.409 & 0.103 & 3.98 & 0.000 & 1.52 \\
\hline $9=$ Harari & 0.403 & 0.108 & 3.73 & 0.000 & 1.52 \\
\hline $10=$ Dire Dawa & 0.286 & 0.102 & 2.81 & 0.005 & 1.81 \\
\hline $11=$ Addis Ababa & 0.582 & 0.088 & 6.61 & 0.000 & 2.85 \\
\hline \multicolumn{6}{|l|}{ Marital status: } \\
\hline $1=$ married & 0.042 & 0.070 & 0.60 & 0.548 & 3.97 \\
\hline $2=$ divorced & -0.371 & 0.124 & -3.00 & 0.003 & 1.81 \\
\hline $3=$ widowed & -0.289 & 0.140 & -2.06 & 0.042 & 2.94 \\
\hline \multicolumn{6}{|l|}{ Educational level of parents: } \\
\hline 1 =basic/adult education & 0.201 & 0.075 & 2.68 & 0.008 & 1.10 \\
\hline 2 = elementary school & 0.014 & 0.080 & 0.18 & 0.861 & 1.15 \\
\hline $3=$ secondary school and above & 0.726 & 0.202 & 3.59 & 0.000 & 1.10 \\
\hline Entrepreneurship training: $1=$ no & -1.113 & 0.266 & -4.18 & 0.000 & 2.24 \\
\hline Number of courses attended & -0.008 & 0.022 & -0.36 & 0.713 & 1.31 \\
\hline Previous business experiences: $1=$ no & 0.098 & 0.034 & 2.88 & 0.004 & 1.31 \\
\hline Enterprise's license: $1=$ yes & -0.076 & 0.032 & -2.38 & 0.017 & 1.18 \\
\hline Access to market: $1=$ no & -0.018 & 0.035 & 0.51 & 0.616 & 1.46 \\
\hline Raising initial finance: $1=$ no & -0.004 & 0.036 & -0.11 & 0.913 & 1.39 \\
\hline Supply of raw material: $1=$ no & 0.071 & 0.035 & 2.03 & 0.042 & 1.42 \\
\hline Lack of supporting institutions: $1=$ No & -1.091 & 0.264 & -4.13 & 0.000 & 1.32 \\
\hline Enterprises registration and permit regulations: $1=$ no & -0.050 & 0.034 & -1.47 & 0.143 & 1.38 \\
\hline Harmful traditional culture: $1=$ no & -0.020 & 0.034 & -0.58 & 0.561 & 1.28 \\
\hline Economic policy (uncertainty): $1=$ no & -0.044 & 0.039 & -1.13 & 0.261 & 1.74 \\
\hline Constant & 3.994 & 0.121 & 33.01 & 0.000 & \\
\hline
\end{tabular}

Number of obs $=695$

$F(31,663)=20.34^{* * *}$

Prob $>F=0.000$

$R^{2}=0.4875, \operatorname{Adj} R^{2}=0.4635$, level of significance is at $a=5 \%$ and $10 \%$

Source: World Bank Data, 2014

Improving access to the education level of entrepreneurs is essential to combating and preventing factors that affecting women entrepreneurs' economic growth (Nchimbi, 2002; Ray \& Ray, 2011; Roomi \& Parrott, 2008; Sumaira et al., 2013; Tambunan, 2009; Wasihun, 2010; Wolday et al., 2015; Zewde and Associates, 2002). This is 
consistent with the current study. The result of the present study shows that the educational level of entrepreneurs is positively related with the economic achievement of women entrepreneurs which implies that higher education may facilitate entry in the business activities, can enhance the managerial ability of the individual, and hence increase the propensity to undertake to participate in entrepreneurial activity.

The current study is in agreement with the previous studies which pointed out that a large number of women who engaged in small enterprises affect the entrepreneurs' economic achievement (Coleman, 2002; Desta, 2010). The current finding shows that family size positively determines the economic growth of women entrepreneurs. This may imply that an increasing number of entrepreneurs in different business activities from family help households to generate more income and develop their economies. Table 4 tells us that the number of financially dependent people negatively related to the economic achievement of women engaged in business activities.

This study found evidence that entrepreneurial area or residence is an important component of economic achievement. Results in Table 4 reveal that women entrepreneurs who run their entrepreneurial activities in the rural area were generating less income as compared to those who run their business activities in an urban one. The reason might be that women entrepreneurs who run their entrepreneurial activities in the rural area have not got access to raw materials, access to finance, access to the market, and others. These findings are also supported by previous studies (Nelso \& Ikandilo, 2011; Singh \& Belwal, 2008).

The business experience gained from their family members, friends, and others may influence the economic achievement of women entrepreneurs. This is in agreement with the findings in other studies (Nchimbi, 2002; Roomi \& Parrott, 2008; Wasihun, 2010). In addition to this, the findings show that the income of women entrepreneurs who have the enterprise's license less than those who do not have the enterprise's license controlling for other variables in the model. This result is in agreement with a previous study (Wole, 2004). This reason might be that entrepreneurs who do not have the license they fail to pay tax for the government, whereas entrepreneurs who have licenses pay tax for the government.

Entrepreneurship training improves the economic growth of entrepreneurs (Nchimbi, 2002; Singh \& Belwal, 2008; Tambunan, 2009; Teresia, 2014; United Nations, 2006; Zewde and Associates, 2002). This is in agreement with the current study which implies that women entrepreneurs who did not take entrepreneurship training were generating less income than women entrepreneurs who took entrepreneurship training while keeping other variables constant. This implies that trained women entrepreneurs will have a better opportunity to manage their enterprises and generate more income when compared with those not trained.

The current findings also pointed out that women entrepreneurs who do not have the availability of raw material or lack of access to raw material generated less income as compared to women entrepreneurs who have available raw materials while controlling other variables in the model. This finding is also in line with other previous studies (Roomi \& Parrott, 2008; Sumaira et al., 2013; United Nations, 2006). The present study result shows that the availability of raw materials positively influences the economic achievement of women entrepreneurs. On the other hand, the current study revealed that the entrepreneurs who do not have supporting institutions were generating less income than those who have supporting institutions keeping constant other variables in 
the model. The other findings also support the current results (Desta, 2010; Jemal, 2013; Melat, 2015; Roomi \& Parrott, 2008; Singh \& Belwal, 2008; Sumaira et al., 2013; Wolday et al., 2015).

Furthermore, the present study finds out that the marital status of entrepreneurs negatively affects the economic achievement or growth of women entrepreneurs. This indicates that divorced and widowed entrepreneurs women are found to generate less income as compared to single groups. Generating less income may not allow the divorced and widowed women entrepreneurs to concentrate on different enterprises or other works as required. Besides, improving the educational level of parents is important for combating and preventing the determinants of economic growth of women entrepreneurs.

Moreover, the current findings illustrated that the region where the women entrepreneurs run their enterprises significantly affects in generating their income of women entrepreneurs. This result shows that women entrepreneurs who engaged in entrepreneurial activities around Afar, Amhara, Oromiya, SNNP, Gambella, and Harari regions were generating less income than women entrepreneurs in the Tigray Region while controlling other variables in the model. Similarly, women entrepreneurs who run their entrepreneurial activities in Dire Dawa administration town and Addis Ababa City were generating less income as compared to those in the Tigray Region keeping other variables constant. In conclusion, even if the current finding is in agreement with different previous studies or literature mentioned above, but contradict with regard to the model they employed to analyze the results, and other variables such as the number of financially dependent people on women entrepreneurs, region, marital status, and educational level of parents.

Therefore, education level, family size, enterprises residence, region, marital status, educational level of parents, number of financially dependent people, entrepreneurship training, previous business experiences, enterprise's license, availability of raw materials, and lack of supporting institutions are some of the crucial barrier determinants that affect the women entrepreneurs. On the contrary, age of women entrepreneurs, region (Somalia and Benishangul Gumuz), marital status (married), number of training attended access to market, raising initial finance, enterprises registration and permit regulations, harmful traditional culture, and economic policy (uncertainty) do not have any significant impact on the economic achievement of women entrepreneurs.

\section{Conclusions}

Based on the findings of this study, the following conclusions are made. Firstly, the educational level of women entrepreneurs and parents are the most important component for economic achievement of women entrepreneurs. Secondly, family size is also an important variable to increase the economy of women entrepreneurs which implies that large family generates more income by participating in different works and reduces workloads. In addition to this, women entrepreneurs who financially support more people generate less income than others. Thirdly, previous business experience, offering entrepreneurship training, less availability of raw material (inputs), and lack of supporting institutions are significant factors of women entrepreneurs' economic growth. This implies that women entrepreneurs who have experiences and offered entrepreneurship training were generating more income as compared to those who do not have 
experiences and not trained. Fourth, divorced and widowed women entrepreneurs are found to generate less income as compared to single groups. Generating less income may not allow the divorced and widowed women entrepreneurs to concentrate on different business activities or other works as required. Although, the economic success of women entrepreneurs who were running their enterprises in Afar, Amhara, Oromiya, Southern Nations Nationalities and Peoples, Gambella and Harari regions; Dire Dawa and Addis Ababa administrative city were less as compared to women entrepreneurs engaged enterprises in Tigray Region.

Based on the findings of this study, the following policy implications are made: firstly, there is a need to give attention to the women entrepreneurs' education and parents' education. Therefore, the relevant authorities or policy-makers should develop a program that gives awareness of the education of women entrepreneurs. Secondly, there is a need to increase the number of participants in business activities within the appropriate entrepreneurial area. Therefore, the government or policy-makers should increase the capacity of entrepreneurs through awareness creation, financial support, providing entrepreneurship training, and increasing the availability of raw materials and other facilities. Thirdly, it is better if the government or concerned body gives special attention to divorced and widowed households. This may include awareness creation, financial support or creating a good condition/atmosphere for them.

Moreover, it is advisable if the business participation status of women be assessed periodically to monitor the situation and to take appropriate measures for combating and preventing the challenges facing women entrepreneurs' in economic growth.

Abbreviations

ESD: Enterprises Survey Data; MSEs: Micro and small enterprises; OLS: Ordinary least squares; SNNP: Southern Nations Nationalities and Peoples; UN: United Nations; VIF: Variance inflation factor; WB: World Bank

Acknowledgements

I acknowledge the Ethiopian Central Statistical Agency for providing me the data.

Author's contributions

The author has contributed substantially to the development of the manuscript. The author read and approved the final manuscript.

Funding

Not applicable for this section.

Availability of data and materials

I can provide the dataset that has been used during the current study on reasonable request.

Competing interests

The author declares that he has no competing interests.

Received: 14 August 2019 Accepted: 7 December 2020

Published online: 03 February 2021

\section{References}

Agarwal, S., \& Lenka, U. (2016). An exploratory study on the development of women entrepreneurs: Indian cases. Journal of Research in Marketing and Entrepreneurship, 18, 232-247.

Amha, W., \& Admassie, A. (2004). Rural financial intermediation program and its role in strengthening the rural financial system in Ethiopia. Journal of Microfinance Development Review, 232-365.

Amha, W., \& Narayana, P. (2004). Review of the microfinance industry in Ethiopia: Regulatory Framework and Performance. Addis Ababa: Ethiopian Ministry of Trade and Industry.

Aregash, A. (2005). Public-Private Partnership Projects of the GTZ in Ethiopia. Eschborn: International trade and the protection of natural resources in Ethiopia Bonn.

Baron, R. A. (2007). Behavioral and cognitive factors in entrepreneurship: Entrepreneurs as the active element in new venture creation. Strategic Entrepreneurship Journal, 1, 167-182.

Beshir, S., Adem, K., \& Belaineh, L. (2016). Determinants of Participation in Entrepreneurial Activities in Arsi Zone, Oromiya, Ethiopia. Arsi Journal of Sciences and Innovations, 1, 83-104. 
Bhardwaj, B. R. (2014). Impact of education and training on the performance of women entrepreneurs a study in the emerging market context. Journal of Entrepreneurship in Emerging Economies, 6(1), 38-52.

Bushell, B. (2008). Women entrepreneurs in Nepal: what prevents them from leading the sector. Gender and Development, 16, $549-564$.

Coleman (2002). Constraints faced by women small business owners. Evidence from the Data. Journal of Development Entrepreneurship, 7(2), 151-174.

Desta, S. (2010). Desk Review of Studies Conducted on Women Entrepreneurs in Ethiopia. Addis Ababa: Addis Ababa Chamber of Commerce and Sectoral Associations.

Eshetu, B., \& Zeleke, W. (2008). Women entrepreneurship in micro, small and medium enterprises: the case of Ethiopia. Journal of International Women's Studies, 10(2), 3-19,

Ethiopian Economic Association (2004). Industrialization and Industrial Policy in Ethiopia: Report on Ethiopian Economy, Volume III. Addis Ababa: Ethiopian Economic Association.

Geda, A., Shimeles, A., \& Weeks, J. (2009). Growth, poverty, and inequality in Ethiopia: which way for pro-poor growth? Journal of International Development, 21, 947-970.

Gujarati, D. N. (2004). Basic econometrics, (4th ed.). New York: The McGraw: Hill Companies.

Gujarati, D. N., \& Sangeetha (2007). Basic Econometrics, (4th ed., ). New Delhi: Tata McGraw-Hill.

Hisrich, R. D., Peteris, M. P., \& Shepherd, D. A. (2008). Entrepreneurship, (7th ed., ). New York: McGraw-Hill Co.Inc.

Jemal, A. (2013). Challenges confronting women in micro and small enterprises in Addis Ababa, Ethiopia. Ethiopian Journal of Business and Economics, 3(1), 96-139.

Koutsoyiannis, A. (2001). Theory of econometrics: an introductory exposition of econometric methods. Ontario: Palgrave.

Melat, T. (2015). Women's entrepreneurship development in Ethiopia a case study of women in self employment.

Nchimbi (2002). Gender and entrepreneurship in Tanzania: a comparative analysis of male-female's start-up motivation, individual characteristics, and perceptions of business success, Ph.D. Thesis, University of Dar Es Salaam.

Nelso, J., \& Ikandilo, K. (2011). Challenges facing women micro-entrepreneurs in Dar Es Salaam, Tanzania. International Journal of Human Resource Studies, 1(2), 1-9.

Nieman, G. H., \& Nieuwenhuizen, C. (2003). Entrepreneurship. A South African Perspective, (2nd ed., ). Pretoria: Van Schaik.

Normaizatul, A. S., Norhanizah, J., \& Hamidah, R. (2017). Determinants of women entrepreneurs' performance in small and micro enterprises: conference paper. The University of Tenaga Nasional.

Okafor, C., \& Mordi (2010). Women entrepreneurship development in Nigeria: the effect of environmental factors. Economic Sciences Series, to the Development and Progression of Women, 14(3), 43-52.

Olomi RD, Sinyamule (2007) Entrepreneurial inclinations of vocational education students. a comparative study of male and female trainees in the Iringa region, Tanzania Uongozi. Journal of Enterprising Culture, 17, 103-125.

Pandian, K., \& Jesurajan, V. (2011). An empirical investigation on the factors determining the success and problems faced by women entrepreneurs in Tiruchirapalli district-Tamilnadu. Interdisciplinary Journal of Contemporary Research in Business, 3, 9-14.

Rahmato, D. (2004). Searching for tenure security? The land system and the new policy initiatives in Ethiopia. Report prepared for the Forum for Social Studies of Addis Ababa University. Addis Ababa: Addis Ababa University.

Ray, S., \& Ray, I. A. (2011). Women entrepreneurship in India: some critical issues and challenges. International Journal of Contemporary Business Studies, 6-30.

Roomi, M. A., \& Parrott, G. (2008). Barriers to development and progression of women entrepreneurs in Pakistan. Journal of Entrepreneurship, 17, 59-72.

Shane, S., \& Venkatarman, S. (2000). The promise of entrepreneurship as a field of research. Academy of Management Economics, 33, 141-149.

Singh, G., \& Belwal, R. (2008). Entrepreneurship and small and micro enterprises in ethiopia: evaluating the role, prospects, and problems faced by women. Gender in Management. An International Journal, 23(2), 120-136.

Smile, D. (2008). Women entrepreneurs in small and medium enterprises (SMEs) in Ghana. Australia: University of Technology Victoria.

Sumaira, A., Madiha, L., \& Muhammad, W. A. (2013). Problems faced by women entrepreneurs and their impact on working efficiency of women in Pakistan. Middle-East Journal of Scientific Research, 18(8), 1204-1215.

Tambunan, T. (2009). Women entrepreneurship in Asian developing countries: their development and main constraints. Journal of Development and Agricultural Economics, 1, 27-40.

Teresia, N. K. (2014). Challenges facing women entrepreneurs in Africa - a case of Kenyan Women entrepreneurs. International Journal of Advances in Management, Economics, and Entrepreneurship, 1(2), 1-8.

The World Bank (2014). Socioeconomic Survey 2013-2014, Ethiopia. https://microdata.worldbank.org/index.php/catalog/2247

United Nations (2006). Entrepreneurship and e-business development for women. Thailand: United Nations Publications.

Wang, C., Walker, E. A., \& Redmond, J. (2006). Ownership motivation and Strategic Planning in Small Business. Journal of Asia Entrepreneurship and Sustainability, 2(4), 1-14.

Wasihun, R. (2010). Growth determinants of women-operated micro and small enterprises in Addis Ababa, (pp. 1-26).

Wolday, A., Tassew, W., Eyoual, T., \& Aregawi, G. (2015). The characteristics and determinants of entrepreneurship in Ethiopia. Ethiopian Journal of Economics, 24(1), 131-165.

Wole, S. (2004). The micro and small enterprises sector in Ethiopia: an overview. the report was produced for the Ministry of Finance and Economic Development. Addis Ababa: Ministry of Finance and Economic Development.

Zewde and Associates (2002). Jobs, gender and small enterprises in Africa: women entrepreneurs in Ethiopia. A preliminary report. Geneva: ILO, IFP/SEED-WEDGE, Oc.

\section{Publisher's Note}

Springer Nature remains neutral with regard to jurisdictional claims in published maps and institutional affiliations. 